\title{
CSF3 Gene
}

National Cancer Institute

\section{Source}

National Cancer Institute. CSF3 Gene. NCI Thesaurus. Code C24312.

The gene is involved in the regulation of the progenitor cells for granulocytes. 